\title{
BRIDE BEHIND THE THRESHOLD: “THE LAY OF THE NIBELUNGS”, BODY-SHIFTERS AND THE MYTHOLOGY OF EXOGAMIC MARRIAGE
}

\author{
Asia A. Sarakaeva (a), Elina A. Sarakaeva (b) \\ (a) Hainan University. Haikou, China. Email: 1977487 837[at]qq.com \\ (b) Hainan College of Economics and Business. Haikou, China. Email: 2689655 292[at]qq.com
}

\begin{abstract}
Basing on the German epic poem "The Nibelungenlied" and European folk tales, authors of the article single out the story of a bride left nearby her groom's house. Characteristic features of this story are explained as originating from a ritual myth which used to codify the rites of the exogamic marriage. The bride in this plot is viewed as a shape-shifter whose bodily transformations reflect her origins from the Underworld and manifest her ability to kill. Changing the bodily form is thus representative of the evil powers and dangerous qualities of a being. The transformations of the bride's body are only present in the most archaic forms of the plot, where her ability and proneness to kill are manifested straightforwardly - by assuming the image of a murderous animal. It's possible to neutralize her harmful potency with the help of a wonderful assistant, the dead man who embodies one's ancestor, or by performing certain ritual actions, creating special conditions under which the bride could change and become one of our own, safe for herself and her host family, rejecting all ties with the dangerous space of the Otherworld.
\end{abstract}

Keywords

The Nibelungenlied; Folk Tale; Exogamic Marriage; Mythology; Rite; Shape-Shifting

This work is licensed under a $\underline{\text { Creative Commons «Attribution» } 4.0 \text { International }}$ License. 


\section{НЕВЕСТА ЗА ПОРОГОМ: «ПЕСНЬ О НИБЕЛУНГАХ», ОБОРОТНИ И МИФОЛОГИЯ ЭКЗОГАМНОГО БРАКА}

\section{Саракаева Ася Алиевна (a), Саракаева Элина Алиевна (b)}

(a) Хайнаньский университет. Хайкоу, Китай. Email: 1977487 837[at]qq.com

(b) Хайнаньский Институт экономики и бизнеса. Хайкоу, Китай. Email: 2689655 292[at]qq.com

\section{Аннотация}

В статье на материале эпической поэмы «Песнь о Нибелунгах» и сказок европейских народов выделяется сюжет о невесте, оставленной подле дома жениха. Авторы рассматривают и объясняют особенности этого сюжета, возводя его к ритуальному мифу, кодифицирующему правила заключения экзогамного брака. Невеста в рамках этого сюжета рассматривается как оборотень, чьи телесные трансформации отражают ее генетическую связь с миром мертвых и ее способность убивать. Таким образом, изменение телесной формы является отражением злых сил и опасных качеств этого существа. Изменения тела невесты присутствуют только в самых архаичных формах сюжета, где ее способность и склонность к убийству проявляются прямо - путем принятия образа зверяубийцы. Нейтрализовать ее вредную потенцию можно с помощью чудесного помощника-покойника, олицетворяющего предка, или путем совершения определенных ритуальных действий, создания особых условий, при которых невеста могла бы измениться и стать одной из наших, безопасной для себя и своей семьи, отвергающей все связи с опасным пространством потустороннего мира.

\section{Ключевые слова}

«Песнь о Нибелунгах»; Сказка; Экзогамный Брак; Мифология; Ритуал; Оборотничество

Это произведение доступно по лицензии Creative Commons «Attribution» («Атрибуция») 4.0 Всемирная 


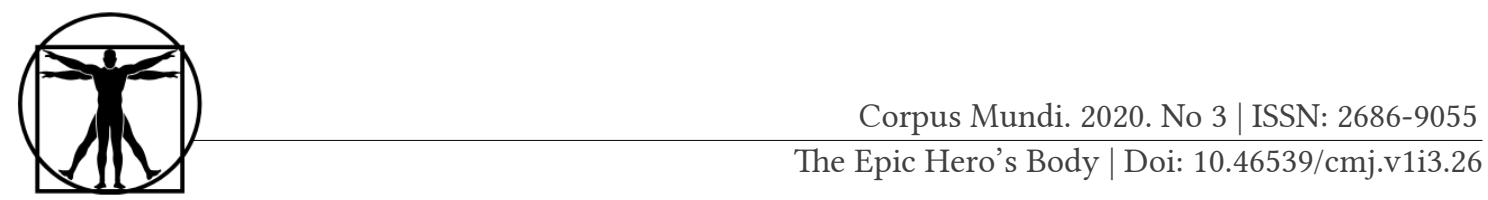

The German epic poem "The Lay of the Nibelungs" is undoubtedly a masterpiece of medieval literature. Its anonymous author is a true storyteller, skillfully weaving into the canvas of his own story numerous motifs and storylines inherited from the previous tradition of Nibelungen tales. His text, in general, is linear, logical and can boast incredible for epic poetry psychological certainty in portraying the characters and their deeds. Nevertheless, there are several episodes in the poem in which the characters commit inexplicable acts, behave inconsistently with logic and their own previously declared intentions. We are convinced that each of these episodes deserves a detailed analysis, since the piling up of controversial actions in the "Lay" does not speak about the author's negligence, but about his attempts to preserve a number of important details inherited from the folk tradition, but not always understood by the author himself. In other words, illogical episodes of the poem are those places where deep tectonic strata of which it is formed come to the surface, and where the researcher has the opportunity to examine or reconstruct the lost traditions and beliefs of the Germanic peoples.

For example, the destruction of the Nibelungen treasure by Hagen and the fuss of all the characters accompanying the act are explained, as we have shown in one of our previous works, by archaic representations of the world order, according to which things from the world of the dead can be used only in the world of the dead, and among the living they sow destruction and death (Sarakaeva \& Lebedeva, 2018, pp. 27-28). These ideas were common in antiquity and in the early Middle Ages, when the legends that formed the basis of the "Lay of the Nibelungs" arose. But by the 13th century, when a poem was written, they were almost lost, and therefore the author himself might not know exactly why his heroes behaved in exactly this way and not otherwise. But the author's conscientiousness, his respect for his material, forced him to preserve whenever possible all significant details, even if they seemed to be making little sense.

This article considers another seemingly illogical episode of the poem, namely, the bridal quest to Iceland. Why do we call this episode illogical? Because throughout its length, the main actor, Siegfried, makes a lot of unnecessary moves, risking the lives of his companions and ruining his own reputation over and over again. We will restore a brief chronology of events.

Upon learning that his friend Gunther wants to get involved with the Icelandic Queen Brunhild, Siegfried warns him of the dangers of this enterprise, because Brunhild is a warrior maiden, and a suitor will have to defeat her in battle, which is very difficult. However, Siegfried undertakes 
to help in this challenge in exchange for a promise that Gunter will give his sister Krimhild to him. Gunther wants to take more warriors along, but Siegfried resolutely objects: in order to impress the proud queen, one must rely only on personal valor, not the number of soldiers and servants. As a result, they travel to Iceland with only four of them - Gunther, Siegfried, the chief vassal of the Burgundian house Hagen and his younger brother Dankwart. In Iceland, Siegfried conceals his status; he calls himself the servant of Gunther and pulls the reigns of the king's horse. At the same time, for some reason, Siegfried is dressed in embroidered white clothes, just like Gunther, and walks by his side, while the other two vassals walk behind. Such a discrepancy between behavior and the declared social status confuses Brunhild, and subsequently she will waste a lot of energy to find out who Siegfried is after all, whether he is equal to the Burgundian king or his servant (Nibelungenlied, 2010).

Further Siegfried, hidden under the invisibility cloak, passes the combat tests instead of Gunther and defeats the queen. Nevertheless, she is still not quite ready to part with her independence, and convenes her vassals at a wedding feast, which the Burgundians regard as an armed threat. And then Siegfried again undertakes to help - he leaves his comrades in Iceland and goes by boat to the king of the Nibelung dwarfs Albrich for help. This additional journey would be absolutely unnecessary if Siegfried himself at the very beginning had not insisted that the retinue should be left at home. Now, however, he no longer thinks to impress Brunhild with courage, but sets off for the armed squad.

He manages to return with help in time, Brunhild has to submit and to sail with them to Burgundy. Halfway through, Hagen persuades Siegfried to go ahead to Worms and bring the news of their imminent arrival there. This commission, firstly, is humiliating for Siegfried, as it forces him, the prince and the illustrious hero, to perform the work of an ordinary messenger. Secondly, it is simply impracticable and, in fact, useless. Why warn the Burgundians of the return of their king? Was it so important to arrange a ceremonial meeting so that it was worth asking Siegfried to get down to this work because of this? In addition, given that the heroes sailed the sea on the same ship, the question arises, how was Siegfried supposed to get to Burgundy? Was he supposed to somehow get ahead of them on the way, or were they going to land somewhere in order to provide him with a head start?

In Elder Edda, a parallel story about the conquest of Brunhild is given more simply: Sigurd sees a beautiful maiden sleeping in a circle of fire and shields, passes through this obstacle and wakes the beauty. They decide to get married, but first Sigurd leaves her and goes in search of 


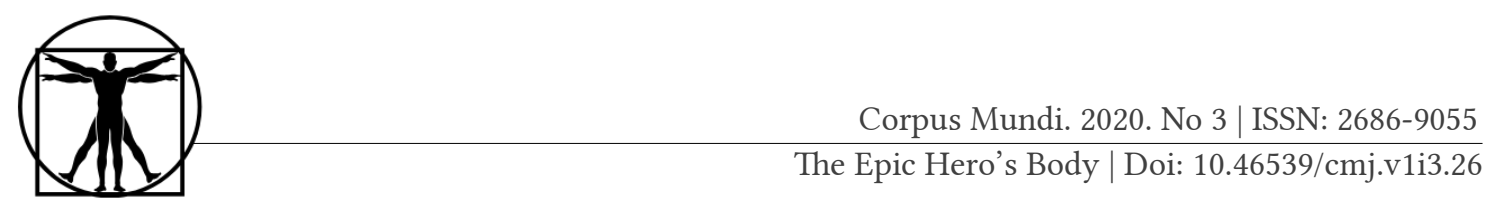

new adventures. When he is staying in the house of the young king Gunnar, the sister of the king, Gudrun, having fallen in love with the guest, gives him a drink of oblivion, and he forgets his bride and marries Gudrun (Elder Edda, 2011). There are no obvious internal contradictions in such a presentation, but the same main question remains: why did not Sigurd marry Brunhild immediately, why was this separation necessary?

If we turn to European folklore in search of answers to these questions, we get an unexpectedly large body of texts with a similar plot: this is the myth of Theseus and Ariadne, and many Russian fairy tales about Vasilisa the Wise ("Ivan the merchant's son and Vasilisa the Wise", "Ivan the marketer's son and Vasilisa the Wise", "Vasilisa the Wise", "Sea King and Vasilisa the Wise", "Ivan the Russian Hero"), and also fairy tales of the Germanic peoples (Norwegian "Castle Soria-Moria" and "Wonder Girl", also a German fairy-tale "Iron Oven" recorded by the German Grimm brothers) (Grimm, 2017). In fact, there are many more such tales, but for operational convenience, we have decided to limit ourselves to an analysis of the above. The main thing that combines these stories with the investigated episode of "Lay" and "Edda" is that the hero gets a beautiful bride from a foreign land, but on the way back he leaves her at some intermediate point near the water, and, returning home, forgets her and is going to marry another person. Moreover, in all these cases, with the exception of the Greek myth, this separation is very strange and illogically justified - the hero wants to warn his parents about the bride's arrival (Why?), or to prepare a wedding (But couldn't the girl be delivered first to the comfort and safety of her new home, and then make preparations?), or to fetch horses and a carriage so that the bride does not go on foot (An unnecessary concern, given that she has already walked a much greater distance on foot).

No matter how this act is rationalized in the fairy tales, it remains the key episode - the hero does not take the bride home, leaving her to wait for his return nearby. Therefore, we combine these narratives into a group of plots "bride behind the threshold". Let us consider in more detail the plot scheme of these tales:

1. The hero goes to foreign lands, most often separated from his homeland by a water obstacle. There he will have to go through difficult trials or defeat a monster. In a number of versions of this plot, it turns out that the parents or fate gave the hero as a slave to the monster, and now the hero tries to free himself. Thus, in all the tales of Vasilisa the Wise, the hero's father promises him to the Sea King or to the King Unbaptized Forehead. The character of the tale "Ivan the Russian Hero" is not promised to anyone, he accidentally 
ends up in a hut where Prince Bear is sitting, however, the Bear, like the Sea King in the above-mentioned tales, immediately begins to give him mortally dangerous tasks under the threat of murder (Afanasyev, 2012). The Athenian prince Theseus goes to Crete as a tribute to King Minos, who orders him to return the ring thrown into the sea (Graves, 2018).

2. The hero passes these tests with the help of the monster's daughter or his female captive. With her help, the hero destroys the evil power or finds a way to escape, and the girl follows him as his bride. In some cases, the monster chases after them, but a wise girl delays or deceives him, and the monster is forced to lag behind.

3. When there is already a little left before the hero's house, then, whether on his own initiative or by the will of the bride, he leaves her to wait by the stream, by the pond, or less often - just in the forest, and goes home. Before this, the heroine sets a number of conditions. Sometimes she tells him not to eat or drink anything in his home, but this condition is optional - it occurs only in two of the tales we have analyzed. In other cases, he is forbidden to mention the bride, to brag about her. The main condition is to avoid contact with women of his family, be it mother, sister, or even all female relatives and neighbors. Vasilisa the Wise instructs: "You can kiss everyone, but do not kiss your godmother, otherwise you will forget me" ("Ivan the marketer's son"), "Do not kiss your sister" ("Sea King"). Nastasya the Beautiful, the daughter of Prince Bear, sighs before separation: "You'll come to your village, you will kiss the women and the girls, you'll have a drink of fresh milk - and then you will forget me!" ("Ivan the Russian hero"). The exception is the myth of Ariadne, abandoned on the island of Navxos on the orders of Dionysus, here the hero Theseus has no intention of returning for her.

4. The hero violates the conditions and immediately forgets his bride. As a rule, it is women from his family who achieve this. In the Norwegian fairy tale "Wonder Girl", the hero sincerely tries to follow the advice of his beloved, he ignores all his relatives, who came to the wedding of his elder brother, and eats nothing until the bride's sister holds out an apple ("Wonder Girl"). In the fairy tale "SoriaMoria" the heroine generally remains on the same island where he freed her from the control of the troll, but he has the opportunity to magically summon her to him, wherever he is. However, before he prepares his house for her arrival, he should not call her there. The neighboring girls, or, in another translation, servants from a neigh- 


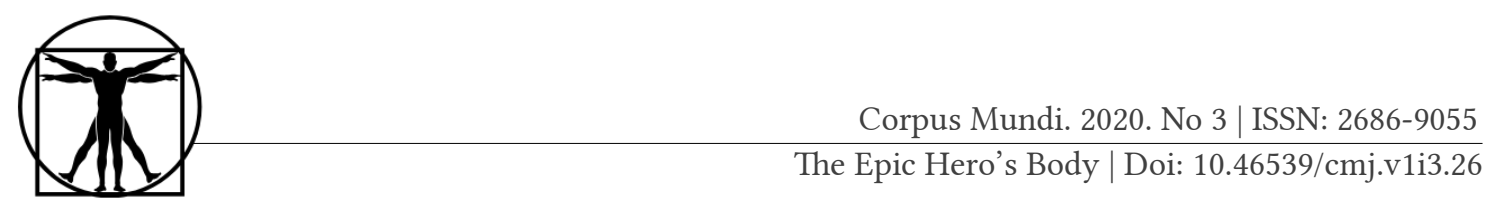

boring castle, are forcing him to violate this ban. Previously, they laughed at the hero and neglected him, and now he wants to show them what beauty he got for his wife (Soria-Moria). Having forgotten the bride, he is going to marry another woman soon. In "Wonder Girl" this other one is even named - this is the sister of his elder brother's bride, the very one who served him an apple (Nordic Tales, 2019).

5. The heroine enters his house unrecognized and at a wedding feast makes him remember her. For this, it is necessary that she conditions someone else to speak about her and her relationship with the hero. The Russian Vasilisa the Wise makes a cake for this, out of which two pigeons fly and enter into a dialogue: the male pigeon asks to feed him and to love him, the female pigeon refuses, least the male pigeon will forget her, just like Ivan forgot Vasilisa. Nastasya the Wise makes pigeons out of dough that come to life at a wedding feast and enter into a similar argument. And the Norwegian Wonder Girl brings with her a hen and a rooster, who begin to fight for an apple. An amused bridegroom exclaims: "Just look at how they are fighting for an apple!" And only then can she remind him of herself: "You and me have also fought this way to regain freedom." As soon as the names of the heroes and the story of their love are heard from the lips of others, then the spell falls from the groom, he recognizes the former bride and takes her as a wife.

So, in all these tales, the hero frees the beauty from the overseas kingdom associated with the chthonic monsters, but for some reason does not bring her home. Obviously, his house and family need some kind of specific preparation in order to be able to receive his bride. Which kind of preparation, however, is completely unclear. Only in one of these stories, "Soria-Moria", does the hero begin to do something unusual when he returns home. Holvar, a kind of Norwegian male Cinderella, prior to his adventures, used to sit all the time at the hearth on a box of ash and pour it between his fingers. And now, having returned after the battle with the trolls, he comes to his father's house and again sits down on this box to play with ash. And only then would his parents, who at first for some reason mistook him for a stranger, recognize him. However, after he meets with the neighboring girls, he violates the ban and summons the bride to come and show herself. Thus, we can no longer find out what he was actually going to do "in the correct way" to bring the beautiful maiden to his house.

But what is this overseas bride who can't simply and without preparation enter her groom's house? From the tales of the "Bride beyond the 
threshold" plot, we learn a little about her: she is a wise beauty, a sorceress, the daughter of a monster or a sea king. In the Russian version, she is associated with waterfowls, because her acquaintance with the hero includes the motive of the stolen clothes / wings. The heroine and her sisters in the form of birds fly to swim in the lake, take off their wings and go swimming. The hero kidnaps the wings or shirt of the most beautiful girl and forces her to promise that she will become his wife ("Ivan the marketer's son", "Vasilisa the Wise", "Sea King and Vasilisa the Wise"). Water in the magical consciousness of ancient Europeans is the gateway to the Otherworld, it is inextricably identified with death. And waterfowls, the inhabitants of both surface and underwater space, are seen as some kind of connecting link between these two worlds, liminal creatures, not completely dead, but not quite alive.

This affiliation of the bride to the chthonic world is more transparent in other European tales, such as, for example, the Icelandic "Tale of Prince Khlinic and Toura the Peasant's Daughter", "Helga the Old Man's Daughter", "Signy and Prince Khlini" (Sigmundsdottir, 2019), the Bulgarian "Good Prince", Russian "Animals' milk", "The Tale of the Prince the Powerful and Ivashka the White Shirt" (Afanasyev, 2012). They lack the motive of leaving the bride behind the threshold, but, just like in the previously described plot, the hero is going to marry a foreign beauty from across the sea.

Moreover, in the aforementioned Icelandic tales, the story, in some way, is mirror-opposite to the plot "Bride behind the threshold". Here the main heroine of the story is not a stranger; she grew up with her lover, was his neighbor, knew him for many years, and helped him escape from the trolls who captured him. And then the hero sees a "marvelous ship" sailing from overseas, and a beauty on this ship, falls in love with her and immediately forgets his former love. As soon as the foreign beauty enters the royal chambers, people begin to disappear there. The heroine convinces the hero to spy on the bride when the later thinks that no one sees her. As a result, they become witnesses of how the foreigner turns into a terrible monster and eats people. The spell immediately falls from the hero, and at the wedding feast he destroys the monster and marries his true bride.

In the above-mentioned Slavic tales, the plot, in general, is quite close to the plot of the "Bride beyond the threshold", with the exception of one important addition - there is a magical assistant there. Thus, in the Bulgarian fairy tale "The Good Prince" and in the Russian "Tale of the Prince the Powerful", the hero honorably buries a dead body that he sees accidentally on his way, and the grateful deceased then rises from the 


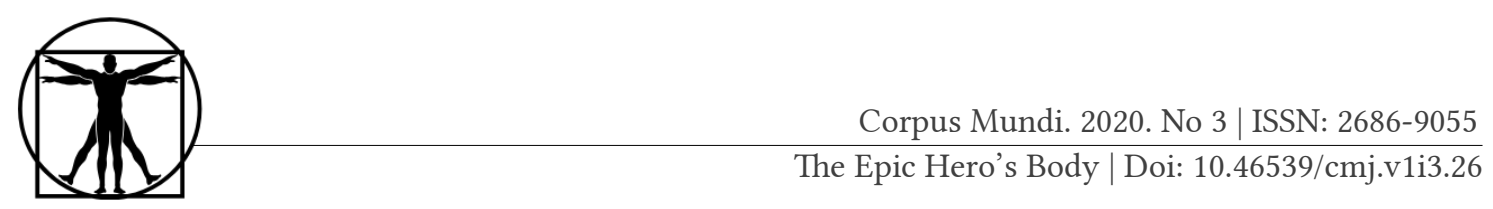

grave to thank the hero for his mercy. In the Russian fairy tale "Animal's milk", a wonderful helper arises from the bones of a dead bull, which also makes him a living dead. When the prince marries a foreign princess, the dead helper keeps watch near the bridal bed and saves the hero from snakes: in the Bulgarian fairy tale they crawl out of the princess's mouth, in the "Tale of the Prince the Powerful" the snake flies to the princess at night. Sometimes the moment of the final purification of the foreign wife from the serpentine essence comes on the way home. Then the magical assistant requires the hero to give him his wife. True to the oath of friendship, the hero is forced to agree, and the magical assistant cuts his wife in half. Snakes fall out of her womb, the hero and his assistant destroy them, after which the assistant revives the woman and returns her to her husband, explaining his behavior: "I only wanted you to never be in danger from the mouth of your wife" ("The Good Prince").

In the famous French legend of the fairy Melusine, the heroine is doomed to turn into a snake below the waist every Saturday. When the young Count Raymond meets her at the spring and falls in love with her, she sets him a condition never to spy on her on Saturdays. But after many years, he violates this requirement, sees her tail and loudly reproaches her for it, calling her a "vile snake". After that, she immediately disappears from his house (Delacroix, 2015). Melusine was considered the ancestor of the powerful aristocratic family of the Lusignans; for this or some other reason the legend does not contain any mention of the harm caused to people around her. However, in one version of the legend it is said that she gave birth to many sons, they all became brave and strong knights, but each was marked by some ugliness, which also hints at their genetic connection with the Underworld.

As we see, the foreign beauty in all these tales is the representative of the underground and underwater world, a product of chthonic monsters, half human - half snake-like creature. The shape-shifting, changing the bodily form is thus representative of the evil powers and dangerous qualities of a being. The transformations of the bride's body are only present in the most archaic forms of the plot, where her ability and proneness to kill are manifested straightforwardly - by assuming the image of a murderous animal. In the more elaborate versions of the plot, "The Lay of the Nibelungs" one of them, shape-shifting of the bride is nearly eliminated; we say nearly because there is still some transformation in Brunhild's body caused by her defeat in the contest and subsequent "taming" in the bridal chamber. From the first moment she appears in the epic she is described as a real beauty, and that suggested for a medieval reader that she looked tender and did not have visible muscles, but her looks are an 
illusion as she possesses extraordinary strength, yet after she marries and submits to her husband the strength leaves her, and her body changes into a usual female body, slender and feeble, and always equal to itself. Siegfried here plays the role of the magical assistant who beats the bride at the night of her wedding to drive away the snake that inhabits her body, so as to ensure that Gunter will "never be in danger from the mouth of his wife".

But before a shape-shifting female is properly tamed, letting her enter a human dwelling without first undertaking precautionary measures will provoke her to start eating people, as we have seen in Icelandic folklore. How to neutralize her harmful potency? One does it either with the help of a wonderful assistant, the dead man who embodies one's ancestor, or by performing certain ritual actions, creating special conditions under which the bride could change and become one of our own, safe for herself and her host family, rejecting all ties with the dangerous space of the Otherworld.

What are these conditions? First, it is important to move one step at a time. The hero who has just returned from the realm of death, first needs to get out from under the long shadow cast by the Death: he should not name himself, he should not speak to his family, he shouldn't not eat or drink human food. We assume that the only variant of the correct behavior at this moment can be seen in the Norwegian "Soria-Moria" (Nordic Tales, 2019). The hero of this tale approaches the fire and touches the ash, that is, he establishes contact with the spirits of his ancestors. And at exactly this point the parents recognize him, because he was accepted by ancestral spirits, he became a fully living man, the restrictions are lifted from him.

But not from the bride. She still needs to stay out of the boundaries of family territories. She cannot be invited to the house; she shouldn't be talked about. The women of the groom's family continue to be particularly dangerous for the relationship of the characters. Their contact with the hero can interrupt the process of gradual entry of the bride into the house.

The stages of this process are demonstrated by one of the most popular Russian fairy tales - "The Frog Princess". There is a serpent-maiden in it, who came out of the water, at day inhabitant of two worlds, at night - a beautiful girl, having married the prince, she first settles with him in his private chamber, that is, does not enter the ancestral home where the king and queen live. Then she sends gifts there, then, only at the invitation of the head of the clan, and only for a while, arrives there. The final step would be her final "domestication", when she would no longer have 


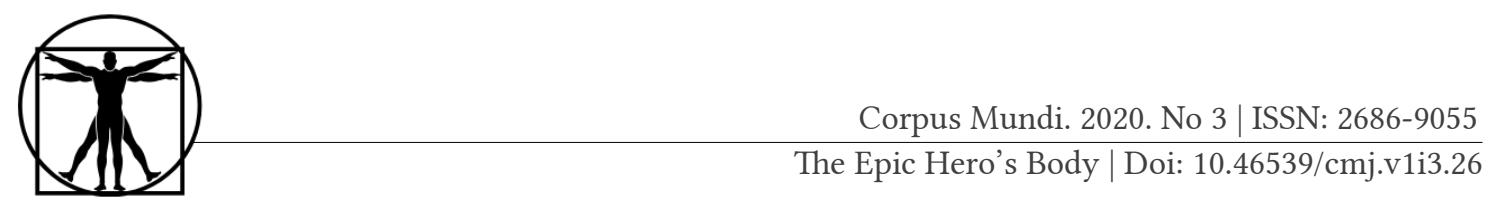

to hide under frog skin. But as soon as the prince deprives her of this protection, she immediately disappears, just like Melusine, or the beautiful princess off the Norwegian tale who flew to the castle of Soria-Moria.

Once frustrated, the process of the bride's entry into the groom's house can be restored either by the efforts of the groom himself, which happens in the fairy tales "Princess Frog" and "Soria-Moria", or - this option is more interesting for us, since it is more common in fairy tales of the studied group and gives more material to analyze - the cunning of the bride. She must enter the house secretly and force others to talk about her, and in well-defined circumstances - at a wedding feast, in the presence of the whole family of the groom. In the Norwegian "Wonder Girl", this public identification at the wedding is preceded by another precaution of the bride. The Wonder girl there provides her fiancé's family with a number of services, lending them the necessary things. When the old king, as a sign of gratitude, wants to invite her to the wedding of his son and sends his servants to her, she refuses: "If he is too good to come to me personally, then I am too good to go to him." Then the king personally comes for her and introduces her to his palace. Thus, the bride receives sanction from the clan of the groom - the head of the clan and the ancestor of her husband brings her into the house, the whole clan is a witness to her identification. And only after receiving such a sanction, the groom also recognizes her, and she can stay with him.

All of the above leads us to the hypothesis that the tales of the "bride beyond the threshold", as well as the serpent-maiden and the dead assistant, take their roots in the mythology of European peoples, namely in the ritual myth that tells about the dangers of exogamous marriage and codifies the procedure of wedding.

In the process of their historical development, most nations of the world came to a more or less strict exogamy, somewhere the community was divided into intermarried phratries, somewhere marriages between people bearing the same surname were forbidden, and in any case, marriages between relatives were significantly limited. Whatever may explain the origin of exogamy: the avoidance of genetic degeneration due to incest, as L.G. Morgan thought (1944), or the need to expand social contacts, as E. Tylor (1889) and K. Levy-Stross (1994) proved, empirical experience shows that exogamy was extremely important for ancient societies.

For example, recently German paleogenetics from the Max Planck Society in Jena and the University of Tübingen discovered tangible evidence of the existence and social conditionality of exogamy at the end of the Neolithic and in the Bronze Age. They studied the remains of people buried in Bavaria, in the Lech river valley, belonging to archaeological 
cultures of cord ceramics, bell-shaped goblets, the early and middle Bronze Age (as a whole from 2750 to 1300 BC). The authors of the study managed to reconstruct six families and track them for the time span of 45 generations. Representatives of these families were buried with rich inventory. Of particular interest are womenfolk's graves: women from rich burials were not only unrelated to rich men, they were born and raised in places separated from the Lech Valley by at least 100 kilometers, most likely in what is now eastern Germany and the Czech Republic. But burials of adult daughters of these prosperous clans were not found. In the poor graves, both men and women were local, but they did not enter into kinship with the aristocracy of the valley. Thus, it turns out that the upper stratum of farmers basically didn't accept local girls from the lower layers of society, instead they married exclusively strangers from the likewise privileged families, and gave their daughters into marriage to distant settlements (Mittnik, 2019, pp. 731-734). The results of this study clearly demonstrate the importance of exogamy for ancient society, and especially for its social elite.

At the same time, exogamous marriage was supposed to be a very dangerous enterprise. A girl from a strange family, abducted from a water place, or even taken from her parents, still remained a stranger, whose true origin, abilities and intentions were unknown - hence the Russian word "nevesta" (bride), which literally means "the unknown one". She could be a daughter of a friend or a trading partner, but could, in fact, turn out to be a shape-shifter who took the form of a human.

In one of our previous works, we have already addressed the theme of the mythology of exogamous marriage in the context of the "Lay of the Nibelungs", proving that in its original form the story of the taming of Brunhild is a myth about a terrible virgin who destroys a man during the first wedding night. Therefore, marrying her is possible only with the assistance of a wonderful helper personifying the spirit of the ancestor (Sarakaeva, Lebedeva \& Frolova, 2015). However, for the ritual-magical consciousness, the problems created by the exogamy custom are not limited to the threat that the groom is exposed to while making sex to a foreign bride. A girl from another world can harm other members of the clan too. In addition, there is an opposite aspect of the problem: for the girl herself, being under someone else's roof can be no less dangerous leaving her parental home, she lost the protection of her own ancestral spirits, and the spirits of the husband's house can be hostile to her.

The solution to this problem, we believe, is the step-by-step entry of the bride into the groom's house, preserved in the plot "bride behind the threshold”. Returning from distant lands to his father's house, the young 
man must first conduct some ritual of purification or ritual recognition by the spirits of his ancestors, and until this ritual is completed, food taboos and prohibition on contacts with relatives are imposed on him. The purpose of such a ban may be twofold: firstly, it could serve as protection for local women who would suffer first if an evil stranger entered the house under the guise of a relative; secondly, women of the groom's clan could be thought of as competitors to an exogamous bride, who is especially vulnerable at that moment. Then, the appearance of a new member in the family should be reported to the ancestors, both living and dead, to obtain their consent, after which the young wife could exchange gifts with her husband's relatives, participate in common work and briefly visit the family home. And only after making sure of her safety for the family team and of the favorable attitude displayed towards her by the spirits of the clan, she is accepted as a full member of the clan. If the procedure is carried out without due care, then, as fairy tales tell us, the bride could turn out to be a snake and begin to destroy new relatives, or she has to run and hide so that the spirits of new family's ancestors would not attack her.

Applying this explanatory model to our own material, we will see that the story of Sigurd and Brunhild in Elder Edda becomes simple and logical. Sigurd freed a girl in an overseas land from a curse, betrothed her, and went home to prepare for marriage according to all the rules dictated by exogamy. However, there, like the male characters of the tales analyzed above, he violated both main taboos - he communicated with Gudrun and drank the beverage she offered, as a result he forgot his own bride. Saying this, we are fully aware that, according to the Eddic songs, the Gyukung house was not Sigurd's home, and Gudrun was not his relative. But "Elder Edda" is neither a myth itself, nor even a work created in very ancient times. The imposition of some motives on others is often found in it. An example of such an overlap is the story of Sigurd and Brunhild. The hero here appears in the function of the groom who left the bride behind the threshold, in particular when he violates the prohibitions by meeting with Gudrun, then he appears in the function of a wonderful assistant when he spends the night with Brunhild, putting a sword oozing poison between her and himself.

In the "Lay of the Nibelungs" we find the same interference of motives (Sarakaeva, 2017). Here, the main line in the legend of Brunhild follows the plot of the serpent-maiden and the magical helper. In the function of the assistant to the groom, Siegfried calls himself a servant; replacing Gunther, he goes through all the competitions with the Icelandic queen and fights her on her wedding night. Only two mysterious Siegfried's journeys overseas remain from the plot of the "bride behind 
the threshold". But both times he leaves when the bride is already obtained - the first time he, just like the hero of Soria-Moria, leaves her on the same island where he conquered her, the second time leaves his comrades and bride just before their arrival home and travels forward to prepare a meeting. Characteristically, he agrees to go to Burgundy precisely in order to see Krimhild and accept the reward from her hands, which also indirectly refers us to the broken taboo for contacts with relative women.

Thus, we have shown that the legend of Brunhild, preserved in the "Lay of the Nibelungs" and in the Elder Edda, can be regarded as a rethinking and belletarization of an ancient ritual myth explaining the origin of religious precautions and rites that arranged the exogamous marriage.

\section{References}

Afanasyev, A. (2012). Russian fairy-tales. The Planet: Illustrated Edition

Cooke, D. A. (Ed.) (2015). Delacroix Claire. An Elegy for Melusine: A Medieval Fairy Tale. Edition

Edwards, C. (Trans.) (2010). The Nibelungenlied. The Lay of the Nibelungs. Oxford University Press.

Graves, R. (2018). The Greek Myths: The Complete and Definitive Edition. Polirom.

Grimm, W. \& Grimm, J. (2017). Complete Folk and Fairy tales. Wisehouse Classics.

Levi-Strauss, K (1994). Primordial thinking. M: Republic.

Mittnik, A. et.al. (2019). Kinship-based Social Inequality in Bronze Age Europe. Science, 366(6466), 731-734.

Morgan, L. H. (1944). Ancient Society. Calcutta: Bharti Library.

Sarakaeva, A., Lebedeva, I. \& Frolova Y. (2015). The Ritual and Mythological Origins of the Lay of Brunhild. In The Seventh International Conference on Eurasian Scientific Development (pp. 25-30). Vienna.

Sarakaeva, A.A. \& Lebedeva I.V (2018). The role of the treasure (Horde) in the medieval German epos "Song about the Nibelungs". In Modern Studies in Linguistics, Literature and Culture. Collection of scientific papers on the materials of the I International Scientific Conference. May 31, 2018. Collection of scientific papers on the materials of the I International Scientific and Practical Conference (pp. 2636). Moscow

Sarakaeva, E. (2017). Nibelungs on the margins: transformation of the Nibelungen legend in the folklore of German-Scandinavian frontier. Fournal of frontier studies, (1), 76-94.

Sigmundsdottir A. (2019) Icelandic Folk Legends: Tales of apparitions, outlaws and things unseen. Little Books Publishing.

The Elder Edda (2011). The Book of Viking Lore. Penguin Classics 
Thynell, U. (Ed.) (2019). Nordic Tales: Folktales from Norway, Sweden, Finland, Iceland, and Denmark (Nordic Folklore and Stories, Illustrated Nordic Book for Teens and Adults). Chronicle books.

Tylor, E. (1889). On a Method of Investigating the Development of Institutions etc. Journal of the Anthr. Institute of Gr.Br. a. Ireland (XVIII).

\section{Список литературы}

Afanasyev, A. (2012). Russian fairy-tales. The Planet: Illustrated Edition

Cooke, D. A. (Ed.) (2015). Delacroix Claire. An Elegy for Melusine: A Medieval Fairy Tale. Edition

Edwards, C. (Trans.) (2010). The Nibelungenlied. The Lay of the Nibelungs. Oxford University Press.

Graves, R. (2018). The Greek Myths: The Complete and Definitive Edition. Polirom.

Grimm, W. \& Grimm, J. (2017). Complete Folk and Fairy tales. Wisehouse Classics.

Levi-Strauss, K (1994). Primordial thinking. M: Republic.

Mittnik, A. et.al. (2019). Kinship-based Social Inequality in Bronze Age Europe. Science, 366(6466), 731-734.

Morgan, L. H. (1944). Ancient Society. Calcutta: Bharti Library.

Sarakaeva, A., Lebedeva, I. \& Frolova Y. (2015). The Ritual and Mythological Origins of the Lay of Brunhild. In The Seventh International Conference on Eurasian Scientific Development (pp. 25-30). Vienna.

Sarakaeva, A.A. \& Lebedeva I.V (2018). The role of the treasure (Horde) in the medieval German epos "Song about the Nibelungs". In Modern Studies in Linguistics, Literature and Culture. Collection of scientific papers on the materials of the I International Scientific Conference. May 31, 2018. Collection of scientific papers on the materials of the I International Scientific and Practical Conference (pp. 2636). Moscow

Sarakaeva, E. (2017). Nibelungs on the margins: transformation of the Nibelungen legend in the folklore of German-Scandinavian frontier. Fournal of frontier studies, (1), 76-94.

Sigmundsdottir A. (2019) Icelandic Folk Legends: Tales of apparitions, outlaws and things unseen. Little Books Publishing.

The Elder Edda (2011). The Book of Viking Lore. Penguin Classics

Thynell, U. (Ed.) (2019). Nordic Tales: Folktales from Norway, Sweden, Finland, Iceland, and Denmark (Nordic Folklore and Stories, Illustrated Nordic Book for Teens and Adults). Chronicle books.

Tylor, E. (1889). On a Method of Investigating the Development of Institutions etc. fournal of the Anthr. Institute of Gr.Br. a. Ireland (XVIII). 